\title{
HARMONI NILAI-NILAI PANCASILA DALAM AGAMA HINDU
}

\author{
Puspo Renan Joyo \\ Jurusan Dharma Duta STAHN-TP Palangka Raya \\ pusporenanjoyo@stahntp.ac.id
}

\begin{abstract}
Pancasila is the foundation and ideology of the state. It is a formula consisted of the essences of the values of customs, cultures, and religions which are highly valued by the Indonesian people. Radicalism, terrorism, religious intolerance, and the attempts to push religion as a new ideology is an anomalous phenomenon against the spirit of Pancasila. There is a problem of understanding of the values of Pancasila from religious perspective. This paper aims at tracking the values of Pancasila in Hinduism, as an effort to correlate the values of Pancasila with Hinduism. The theoretical frameworks and analysis used to help decipher the discussion of this paper were semiotics and content analysis. The results show that the values of Pancasila are in harmony with the values contained in the teachings of Hinduism, such as Godly values, religious tolerance, humanism and brotherhood, unity in diversity, deliberation, and socialjustice.
\end{abstract}

Keywords: Pancasila values, Hinduism values

\section{Pendahuluan}

Pancasila adalah dasar dan ideologi negara. Pancasila menjadi dasar untuk mengatur penyelenggaraan negara dan seluruh warga negara Indonesia. Sebagai ideologi, Pancasila merupakan pandangan hidup (weltanschauun) atau dasar falsafah (pilosofische grondslag), jiwa dan kepribadian bangsa atau dapat dimaknai sebagai sistem kehidupan nasional yang meliputi aspek etika atau moral, ekonomi, sosial budaya, dan pertahanan keamanan dalam rangka pencapaian cita-cita dan tujuan bangsa yang berlandaskan dasar negara.

Pancasila merupakan refleksi dari nilai-nilai adat-istiadat, kebudayaan serta nilai-nilai religius, sehingga materi Pancasila yang berupa nilai-nilai tersebut tidak lain adalah bangsa Indonesia sendiri, sehingga bangsa Indonesia sebagai kausa materialis Pancasila. Nilai-nilai tersebut kemudian diangkat dan dirumuskan secara formal oleh para pendiri negara untuk dijadikan sebagai dasar filsafat negara Indonesia. Pancasila merupakan karya bersama yang dihasilkan melalui konsensus bersama. Pancasila merupakan titik temu (common denominator) yang menyatukan keindonesiaan, sehingga jelas bahwa penetapan rumusan 
Pancasila merupakan hasil final yang harus dijunjung tinggi oleh setiap warga ne gara Indonesia d a la m mengembangkan kehidupan kebangsaan dan kenegaraan. (Kaelan, 2004:12; Mulyadi, 2014:1). Meminjam Prof. Dr. Nicolaus Driyarkara, SJ (Riyanto, Astim, 2006:10), Pancasila merupakan dasar terbaik bagi negara Indonesia yang memiliki kebenaran fundamental yang kaya raya.

Negara Kesatuan Republik Indonesia (NKRI) 72 tahun berdiri. Usia yang tidak lagi muda bila ukurannya adalah manusia. Alih-alih bangsa ini telah "selesai" dengan Pancasila, secara De facto, terjadi anomali. Realitas sekarang sebagian anak bangsa justru menunjukkan pemikiran, sikap dan tindakan yang menjauh dari ideal Pancasila. Ironisnya, fenomena ini telah merambah pada kalangan terpelajar yang semestinya menjadi role model insan-insan Pancasilais. Lahirnya PP No.2 tahun 2017 tentang organisasi kemasyarakatan dan Perpres No.54 tahun 2017 tentang Unit Kerja Presiden Pembinaan Ideologi Pancasila, mengindikasikan bahwa eksistensi Pancasila sebagai dasar dan ideologi negara dalam ancaman. Massifnya radikalisme, terorisme, intoleransi agama dipelbagai wilayah di Indonesia, dan peristiwa terbaru, yakni dicabutnya status badan hukum salah satu ormas berhaluan non Pancasila oleh Dirjen
AHU Kemenkumham serta seruan Kemenristek Dikti kepada dosen, pegawai dan mahasiswa untuk keluar dari kampus apabila tergabung dalam organisasi yang ideologinya tidak sejalan dengan pancasila adalah bentukbentuk nyata ancaman itu (Kompas.com; Tribunnews.com).

Menilik catatan sejarah, gerakangerakan yang berupaya "menggoyang" Pancasila senantiasa bertalian dengan persoalan agama. Sebut saja yang tertua, NII atau DI/TII (1949-1965), kemudian GAM (1976-2005) walau memilih nasionalisme Aceh sebagai isu populisnya namun kesan agama sangat terasa, dan hingga saat ini gerakangerakan tersebut juga masih setia pada isu sama, "agama". Pada materi sosialisasi Empat Pilar MPR RI menyatakan bahwa salah satu penyebab situasi ini terjadi karena kurangnya pemahaman, penghayatan, dan kepercayaan akan keutamaan nilai-nilai Pancasila (Tim Penyusun, 2015:103104). Hemat saya, individu, kelompok atau organisasi yang berideologi anti Pancasila merupakan fenomena "gagal paham", yakni gagal dalam memahami, menerjemahkan dan mengorelasikan nilai-nilai agama dengan nilai-nilai Pancasila. Implikasinya, muncul kesan bahwa nilai-nilai agama dan nilai-nilai Pancasila adalah dua hal tidak bertalian satu sama lain.

Pelbagai kajian menunjukkan 
bahwa jiwa manusia memiliki relasi kuat dengan dunia metafisika, religius dan spiritual (vertical-transcendental). Dalam kajian filsafat, Harold H. Titus (Suriasumantri, 1987:32) menyatakan bahwa karakteristik manusia adalah worship and faith in a higher power (sikap bhakti dan keyakinannya terhadap kekuatan yang lebih tinggi), atau Francis bacon yang berpendapat bahwa perenungan yang mendalam akan mengantarkan manusia pada pemikiranpemikiran tentang keagamaan atau religiusitas "... depth in philosophy bringeth men's minds about to religion". Begitu pula dalam kajian psikologi menunjukkan bahwa kebutuhan manusia itu bukan hanya terbatas pada kebutuhan makan, minum, pakaian ataupun kenikmatan-kenikmatan lainnya. Berdasarkan hasil riset dan observasi, mereka mengambil kesimpulan bahwa pada diri manusia terdapar semacam keinginan dan kebutuhan-kebutuhan lainnya, bahkan mengatasi kebutuhan akan kekuasaan. Keinginan akan kebutuhan tersebut merupakan kebutuhan kodrati, berupa keinginan untuk mencintai dan dicintai Tuhan (Jalaludin, 2011:53).

Kedua kajian di atas menunjukkan bahwa eksistensi agama sesungguhnya telah mengakar dalam setiap pribadi manusia. Secara alamiah, manusia telah dilengkapi dengan spirit religius yang kuat. Agama menjadi semacam hal primer. Secara hierarki, agama menduduki tempat teratas dalam skema kebutuhan manusia, sekaligus mengatasi urusan-urusan duniawi. Fenomena "gagal paham" yang kemudian berpadu dengan spirit religius yang kuat mengakibatkan prasangka bahwa menempatkan Pancasila sebagai ideologi dan dasar negara adalah sebuah "keberhalaan". Pada titik ini menjadi logis ketika beberapa pihak begitu bernafsu ingin melengserkan Pancasila dan digantikan dengan agama sebagai ideologi dan dasar negara.

Negara Indonesia terdiri dari pelbagai agama atau keyakinan yang tumbuh, diantaranya; Islam, Kristen, Katolik, Hindu, Budha, Konghucu, dan kepercayaan-kepercayaan. Menilik keragaman itu, pertanyaan pentingnya kemudian adalah, "Jika bukan Pancasila, agama atau kepercayaan apa yang akan menjadi dasar dan ideologi negara ini ?". Persoalan besar bangsa Indonesia yang terjadi selama ini, u tamanya yang berupaya "menggoyang" Pancasila bermula dari hasrat "kebenaran iman tertentu" untuk dijadikan sebagai satu-satunya sumber nilai dan kebenaran bagi semua orang.

Agama menjadi kata kunci dalam wacana penegakan ideologi negara. Agama menjadi instrumen penting dalam melindungi dan memberi penguatan terhadap Pancasila sebagai dasar dan ideologi negara. Perannya 
adalah menjelaskan kembali bahwa Pancasila merupakan entitas dari nilainilai agama, kebenaran Pancasila adalah kebenaran dari nilai-nilai agama, aktualisasi nilai-nilai Pancasila adalah wujud nyata dari pengamalan nilai-nilai keagamaan, dan menjunjung tinggi Pancasila sama nilainya dengan menjunjung tinggi nilai-nilai kebenaran Tuhan. Dengan demikian, tidak terjadi dilema dan keraguan bagi insan agama dalam memahami, menghayati dan mengamalkan nilai-nilai Pancasila, karena keduanya (Pancasila dan agama) memiliki arah yang sejalan. Apabila hal ini mampu diwujudkan maka niscaya akan terjadi transformasi positif, yakni "energi benci" terhadap Pancasila berangsur akan berubah menjadi "energi cinta".

Tulisan ini dimaksudkan untuk menggali nilai-nilai Pancasila yang ada di dalam agama Hindu sekaligus menunjukkan keselarasan keduanya. Dengan demikian diharapkan menjadi sumbangsih pemikiran dalam memberikan pemahaman bagi umat Hindu khususnya, dalam memahami, mengahayati dan mengamalkan nilainilai Pancasila.

\section{Pembahasan}

\subsection{Nilai-Nilai Pancasila dan Pemaknaannya}

Undang-Undang Dasar Negara Republik Indonesia tahun 1945 yang disahkan pada tanggal 18 Agustus 1945 dimuat dalam Berita Republik Indonesia Nomor 7 tahun 1946. Undang-Undang Dasar tersebut terdiri dari tiga bagian, yaitu pembukaan, Batang Tubuh dan Penjelasan.

Undang-Undang Dasar Negara Republik Indonesia tahun 1945 memuat cita-cita kenegaraan (staatsidee) dari cita-cita hukum (reichtsidee), yang selanjutnya dijabarkan dalam pasalpasal Undang-Undang Dasar. Lima Dasar Negara tersebut di dalam Pembukaan alinea keempat, akan tetapi nama Pancasila tidak terdapat secara eksplisit. Secara ideologis, dasar negara yang lima itu adalah Pancasila.

Rumusan lima nilai dasar sebagaimana tercantum dalam pembukaan Undang-Undang Dasar Negara Republik Indonesia tahun 1945 adalah: 1) Ketuhanan Yang Maha Esa; 2) Kemanusiaan yang adil dan beradab; 3) Persatuan Indonesia; 4) Kerakyatan yang dipimpin oleh hikmat k e b i ja k s a a a d a la m permusyawaratan/perwakilan; dan 5) Keadilan sosial bagi seluruh rakyat Indonesia.

Kelima sila tersebut sebagai satu kesatuan nilai kehidupan masyarakat Indonesia dan dasar Negara Republik Indonesia. Dasar tersebut kukuh karena digali dan dirumuskan dari nilai kehidupan rakyat Indonesia yang merupakan kepribadian dan pandangan 
hidup bangsa. Karena itulah Pancasila disepakati secara nasional. Pancasila merupakan suatu perjanjian luhur yang harus dijadikan pedoman bagi bangsa, Pemerintah dan seluruh rakyat Indonesia. Itu pulalah bentuk dan corak masyarakat yang hendak dicapai dan diwujudkan, yaitu masyarakat Indonesia modern, adil, dan sejahtera. Dari sejarah ketatanegaraan terbukti bahwa Pancasila mampu mempersatukan bangsa yang majemuk ini. (Tim Penyusun, 2015:44$45 ;$ ).

Sebagai basis moralitas dan haluan kebangsaan-kenegaraan, Pancasila memiliki landasan ontologis, epistemologis dan aksiologis yang kuat. Setiap sila memiliki justifikasi historis, rasionalitas, dan aktualisasinya, yang jika dipahami, dihayati, dipercayai dan diamalkan secara konsisten dapat menopang pencapaian-pencapaian agung peradaban. Secara ringkas, pokok-pokok moralitas dan haluan kebangsaan-kenegaraan menurut alam Pancasila dapat di elaborasi sebagai berikut:

Pertama, menurut alam pemikiran Pancasila, nilai-nilai ketuhanan (religiusitas) sebagai sumber etika dan spiritualitas (yang bersifat vertikaltransendental) dianggap penting sebagai fundamen etika kehidupan bernegara. Dalam kaitan ini, Indonesia bukanlah negara sekuler yang ekstrim, yang memisahkan "agama" dan "negara" dan berpretensi untuk menyudutkan peran agama ke ruang privat (komunitas). Negara menurut Pancasila bahkan diharapkan dapat melindungi dan mengembangkan kehidupan beragama; sementara agama diharapkan bisa memainkan peran publik yang berkaitan dengan penguatan etika sosial. Tetapi pada saat yang sama, Indonesia juga bukan "negara agama", yang hanya merepresentasikan salah satu (unsur) agama. Sebagai negara yang dihuni oleh penduduk dengan multiagama dan multikeyakinan, negara Indonesia diharapkan dapat mengambil jarak yang sama terhadap semua agama atau keyakinan, melindungi semua agama atau keyakinan, dan harus dapat mengembangkan politiknya yang dipandu oleh nilai-nilai agama. Peran agama dan negara tidak perlu dipisahkan, melainkan dibedakan. Dengan syarat bahwa keduanya saling mengerti batas otoritasnya masingmasing yang disebut dengan istilah "toleransi kembar" (twin tolerations), atau meminjam istilah Fred W. Riggs, Negara Pancasila adalah sebuah religious nation state, yakni sebuah negara kebangsaan yang religius yang melindungi dan memfasilitasi berkembangnya semua agama (Ismail, 2006:42-44).

Kedua, menurut alam pemikiran Pancasila, nilai-nilai kemanusiaan universal yang bersumber dari hukum 
Tuhan, hukum alam, dan sifat-sifat sosial manusia (horizontal) dianggap penting sebagai fundamen etik politik kehidupan bernegara dalam pergaulan dunia. Prinsip kebangsaan yang luas yang mengarah pada persaudaraan dunia itu dikembangkan melalui jalan eksternalisasi, partisipasi aktif dalam ketertiban dunia yang berdasarkan kemerdekaan, perdamaian abadi dan keadilan sosial dan jalan internalisasi, bangsa Indonesia mengakui dan memuliakan hak-hak dasar warga negara. Landasan etik sebagai dasar prasyarat persaudaraan universal ini adalah adil dan beradab. Komitmen bangsa Indonesia dalam memuliakan nilai-nilai kemanusiaan itu sangat visioner, mendahului Universal Declaration of Human Rights yang baru dideklarasikan tahun 1948. Secara teoritik-komparatif, jalan eksternalisasi dan internalisas i dala m mengembangkan kemanusiaan secara adil dan beradab itu menempatkan visi Indonesia dalam perpaduan antara perspektif teori idealisme politik (political idealism) dan realisme politik (political realism) yang beriorientasi kepentingan nasional dalam hubungan internasional.

Ketiga, menurut alam pemikiran Pancasila, aktualisasi nilai-nilai etis kemanusiaan itu terlebih dahulu harus mengakar kuat dalam lingkungan pergaulan kebangsaan yang lebih dekat sebelum menjangkau pergaulan dunia yang lebih jauh. Dalam internalisasi nilai-nilai persaudaraan kemanusiaan ini, Indonesia adalah negara persatuan kebangsaan yang mengatasi paham golongan dan perseorangan. Persatuan dari kebhinekaan masyarakat Indonesia dikelola berdasarkan konsepsi kebangsaan yang mengekspresikan persatuan dalam keragaman, dan keragaman dalam persatuan, yang dalam slogan negara dinyatakan dengan ungkapan Bhineka Tunggal Ika.

Keempat, menurut alam pemikiran Pancasila, nilai ketuhanan, nilai kemanusiaan, dan nilai serta citacita kebangsaan itu dalam aktualisasinya harus menjunjung tinggi kedaulatan rakyat d a la m s e m a n a t permusyawaratan yang dipimpin oleh hikmat kebijaksanaan. Dalam visi demokrasi permusyawaratan, demokrasi memperoleh kesejatian dalam penguatan daulat rakyat, ketika kebebasan politik berkeadilan dengan kesetaraan ekonomi, yang menghidupkan semangat persaudaraan dalam kerangka musyawarah mufakat. Dalam prinsip musyawarah mufakat, keputusan tidak didikte oleh golongan mayoritas (mayorokrasi) atau kekuatan minoritas elit politik dan pengusaha (minorokrasi), melainkan dipimppin oleh hikmat atau kebijaksanaan yang memuliakan daya-daya rasionalitas deliberatif dan kearifan setiap warga 
tanpa pandang bulu.

Kelima, menurut alam pemikiran Pancasila, nilai ketuhanan, nilai kemanusiaan, nilai dan cita kebangsaan, serta demokrasi permusyawaratan itu memperoleh kepenuhan artinya sejauh dapat mewujudkan keadilan sosial. Di satu sisi, perwujudan keadilan sosial itu harus mencerminkan imperatif etis keempat sila lainnya. Di sisi lain, otentisitas pengalaman sila-sila Pancasila bisa ditakar dari perwujudan keadilan sosial dalam perikehidupan kebangsaan. Dalam visi keadilan sosial menurut Pancasila, yang dikehendaki adalah keseimbangan antara pemenuhan kebutuhan jasmani dan rohani, keseimbangan peran manusia sebagai makhluk individu dan peran manusia sebagai makhluk sosial, juga keseimbangan pemenuhan hak sipil dan politik dengan hak ekonomi, sosial dan budaya (Latif, 2011:5-8; Salam, 1996:27 ) .

Dari pemaknaan kelima sila Pancasila di atas, maka ditemukan dan diklafisikasikan kata-kata, frasa, peristilahan atau kalimat (sign) pada setiap sila yang menjadi esensi dari nilainilai Pancasila untuk kemudian di telusur di dalam kesusastraan agama Hindu. Nilai-nilai yang dimaksud adalah:

1) Sila pertama: Kepercayaan terhadap eksistensi Tuhan Yang Esa; religiustas sebagai basis etika berkehidupan dan bernegara; dan menghargai kebebas an berketuhanan.

2) Sila kedua: penghargaan terhadap nilai-nilai kemanusiaan; dan persaudaraan universal yang berlandaskan etik "adil" dan "beradap".

3) Sila ketiga: bervisi Bhineka Tunggal Ika; dan memiliki kehendak untuk bersatu.

4) Sila keempat: menjunjung tinggi kepentingan (umum) rakyat yang dijiwai permusyawaratan yang penuh hikmat.

5) Sila kelima: keadilan masyarakat.

\subsection{Nilai-Nilai Pancasila dalam Agama Hindu}

Berdasarkan esensi nilai-nilai Pancasila yang telah diklafisikan di atas, berikut ini akan ditelusur nilai-nilai tersebut dalam kesusastraan agama Hindu :

\subsubsection{Sila pertama: Kepercayaan terhadap eksistensi Tuhan Yang Esa; religiustas sebagai basis etika berkehidupan dan bernegara; dan menghargai kebebasan berketuhanan}

Berdasarkan penelusuran, dijumpai sloka-sloka (ayat-ayat) di dalam kesusastreaan Veda yang membicarakan mengenai keberadan Tuhan Yang Maha Esa sebagai sumber kehidupan (causa prima), diantaranya : 
1) Rgveda (IV.26.1-3; IV.42.2; X.90.2; VIII.100.4; X.18.4; X.49.6; X.125.1-5; X.125.8) (Titib, 2003:26-27); 2) Atharvaveda (VII.5; VX.8.1; XVI.3.1;); 3) Narayana Upanisad (2) (Titib, 2009:11-12); Titib, 2003.23-24); 4)Vedanta Sutra (1.4.23-27; 2.1.14; 1.1.5-1.4.13) (Viresvarananda, 2004:18); 5) Isa upanisad (1, 4-8, 1217),

6) Brhad-aranyaka upanisad (I.5.1-13; II.1.1-20; III.4.1-2; III.5.1; III.6.1; III.8.1-12; III.9.1-9; IV.1-7; V.3.1; V.4.1; V.7.1); 7) (Radhakrishnan, 1989:248342); Candogya upanisad (III.5.1-4; IV.2.4; VII.1.1-4); 8) Taittiriya Upanisad (II.1.1; II.6.1; II.7.1; II.9.1; III.1.1; III.2.1; III.3.1; III.4.1; III.5.1; III.6.1); 9) Kena Upanisad (I.2-9; II.1-9; III.112; IV.1-9); 10) Katha Upanisad (II.1.12-13; II.3.1); 11) Prasna Upanisad (I.1-4) (Radhakrishnan, 1992:51-771); 12) Samaveda (1.8.70) (Titib, 2003:24); 13) Bhagavadgita (VII.1-30; VIII.1-28; IX.1-34; X.1-42; XI.1-55; XII.1-20; XIII.1- 35; XVIII.178) (Prabhupada, 2006:361-675; 789862); 13) Yajurveda (XL.15; XVII.27; XXXII.1) (Titib, 2003:173).

Berikut ini akan dikutipkan beberapa sloka untuk merepresentasikan agama Hindu tentang keyakinan akan eksistensi Tuhan Yang Esa, yakni :

Yo devanam namadha eka eva Tuhan Yang Maha Esa adalah Satu dan Dia dinamakan dengan namanama yang berbeda-beda. (Yajurveda XVII.3.17).
Yad ekam jyotir bahudha vibhati Ada satu Tuhan Yang Maha Esa, Yang Maha Agung yang bercahaya. Dia bersinar dalam bentuk yang berbeda-beda. (Atharvaveda XIII.3.17). (Titib, 2003:172-173)

Keyakinan Hindu terhadap eksistensi Keesaan Tuhan juga tercermin dalam landasan pokok keimannya (sradha), yaitu Widhi Sradha, adalah keyakinan terhadap keberadaan Tuhan (Brahman).

Aktualisasi keagamaan manusia Hindu terbangun dari tiga pilar utama, yakni tattwa (filsafat atau pengetahuan), etika (adab tindakan), dan ritual (upacara seremonial atau yajna). Dialetika keadaban moral dan laku, dengan demikian tidak dapat dipisahkan dengan agama Hindu. Etika memiliki siginifikansi yang sebanding dengan pelaksanaan tattwa dan ritual. Kealpaan pada aspek etika berakibat pada ketidakseimbangan aktualisasi keagamaan yang ideal. Dalam pelasksanaannya, etika didasarkan atas petunjuk kitab suci, dan norma-norma yang sejalan dengan kitab suci. Standar moral manusia Hindu mengacu pada otoritas kitab suci, bukan spekulasi perasaan pribadi semata. Hal itu dinyatakan dalam kitab suci Manawadharmasastra II.6, sebagai berikut :

Vedo 'khilo dharma mulam, smrti 
sile ca tad vidam

Acarasca iva sadhunam, atmanas tustir eva ca

Veda (Sruti) adalah sumber dari segala sumber dharma, kemudian barulah Smrti (Dharmasastra), di samping Sila (tingkah laku orang suci), Acara (tradisi yang baik) dan Atmanastusti (keheningan hati) (Titib, 2003:28-29).

Kebebasan dalam berketuhanan mendapat tempat yang sangat terhormat dalam agama Hindu. Keragaman menjadi identitas bagi Hinduisme, karena menyadari bahwa setiap manusia memiliki keragaman watak, kemampuan, pengertian, potensi spiritual dan karma. Penyeragaman dipandang sebagai cara pemaksanaan dan irasional. Oleh karena itu akan sangat mudah menyaksikan keragaman dalam banyak hal di dalam agama Hindu. Bagi sebagian orang, bhakti yoga dipandang sebagai yang terbaik, namun ditempat yang berbeda bisa jadi karma yoga, raja yoga atau bahkan jnana yogalah yang dipandang sebagai yang terbaik. Tidak ada pertentangan, semua memiliki esensi kebenaran. Hal itu semata-mata hanya perbedaan cara dan pilihan jalan masing-masing orang. Kitab suci Bhagavadgita 4.11 menjelaskan :

Ye yatha mam prapadyante tams tathi 'va bhajamy aham Mama varta 'nuvartante manushyah partha sarvasah Jalan manapun ditempuh manusia ke arah-Ku, semuanya Ku-terima, dari mana-mana semua mereka menuju jalan-Ku oh Parta. (Pendit, 1996:121-122).

Bila ditarik dalam dimensi yang lebih luas, pesan Bhagavadgita ini dapat dimaknai sebagai bentuk kemerdekaan manusia di dalam menghayati dan mengekspresikan tindakan keagamaannya. Tidak menjadi soal manusia dan identitas keyakinan atau ketuhanannya karena semua menuju yang satu, demikian kurang lebih maknanya. Keberbedaan jalan di dalam Hinduisme bukanlah sebuah persoalan, namun semata-mata hanya pilihan dari jalan, seperti layaknya dua orang sahabat yang ingin menuju sebuah puncak gunung dari tempat yang berbeda.

\subsubsection{Sila kedua: penghargaan terhadap nilai-nilaik e m a n u s i a n ; d a n persaudaraan universal yang berlandaskan etik "adil" dan "beradap".}

Penghargaan terhadap nilai-nilai kemanusiaan dan persaudaraan di dalam Hinduisme di dasarkan atas kesadaran bahwa setiap mahkluk sejatinya memiliki esensi yang sama, perbedaan ragawi tidak merubah esensi itu berbeda. Esensi itu adalah Atman. Hinduisme menerangkan bahwa setiap jiwa, atman yang ada di dalam diri manusia memiliki kualitas yang sama (Bhagavadgita II.2325). "Tat Tvam Asi”, yang berarti "itu 
adalah kau", demikian di jelaskan kitab suci Chandogya Upanisad 6.8.7. Kitab Hitopadesha 1.3.71 dan Maha Upanisad 6.72 menyatakan "Vasudhaiva kutumbakam", semua adalah saudara. Pengetahuan itu memuncak pada kesadaran diri yang tidak terpisah dengan diri yang lain. Ia mengidentifikasi diri lain sebagai dirinya sendiri. Tidak ada konsep liyan atau the others. Cara pandang Hindu tentang kemanusiaan begitu mendalam, melampaui sekat-sekat ragawi. Pesan ini diungkapkan dalam Bhagavadgita 5.18, dan Yajurveda 4.60 :

Vidya vinaya sampanne brahmane gavi hastini Suni chai 'va svapake cha panditah samadarsinah

Orang arif bijaksana melihat semuanya sama, baik brahmana budiman dan rendah hati maupun seekor sapi, gajah, dan ajing ataupun orang hina sekalipun.

Yastu sarvàni bhùtàn yàtmannevànu pasyati sarva bhùtesu càmànamtato na vicikitsati.

Manusia yang bisa melihat semua mahluk dalam dirinya dan melihat rohnya pada mahluk lain. Maka ia tidak akan merasa sedih dan raguragu. Ketahuilah itu.

Pengetahuan dasar ini kemudian diaktualisasikan melalui bentuk-bentuk keadaban tindakan di dalam agama Hindu, diantaranya :

1) Ahimsa, tidak membunuh atau menyakiti mahkluk atau manusia yang lain. Dalam pendekatan yang lebih operasional, ahimsa dapat dimaknai sebagai tidak menistakan atau melecehkan keyakinan orang lain, kekurangan orang lain, mempermalukan orang lain, merendahkan harga diri orang lain, dan lain sebagainya. Redamnya hasrat menyakiti dipandang sebagai dharma yang termulia. Kitab suci Vana Parva menjelaskan sebagai berikut : ahimsā satyavacanam sarvabhūtahitam param ahimsā paramo dharmah sa ca satye pratisthitah satye krtvā pratisthām tu pravartante pravrttayah Mereka yang bathinnya mulia tidak menyakiti dan penuh kebaikan kepada semua mahluk. Ahimsa (tidak menyakiti) adalah dharma yang tertinggi, mereka tidak pernah menyakiti dalam perbuatan, perkataan dan pikiran.

Ajaran ahimsa ini juga dinyatakan dalam kitab Sarasamuccaya $(141,146)$.

2) Mitra, persaudaraan universal. Agama Hindu memiliki pemahaman mendasar tentang arti sebuah persaudaraan. Persaudaraan dalam Hindu tidak bersifat sektoral atau barbasis komunitas tertentu, berdasarkan keyakinan, suku, ras, maupun kewilayahan. Persaudaraan itu 
bersifat menyeluruh, mendasar dan melampaui sekat apa saja. Yajurveda XXX.18 menjelaskan demikian :

Mitrasya ma caksusa sarvani bhutani samiksantam

Mitrasyaham caksusa sarvani bhutani samikse

Mitrasya caksusa samiksamahe

Semoga semua makhluk memandang kami dengan pandangan mata seorang sahabat, semoga saya memandang semua makhluk sebagai seorang sahabat, s e moga kami saling berpandangan penuh persahabatan.

Pesan-pesan persahabatan dan persaudaraan universal di dalam kesusasteraan Hindu juga dinyatakan di dalam kitab suci Hindu yang lain, Atharvaveda (III.30.1; XIX.62.1; XL.7; VII.52.1); Yajurveda (XL.7; 40.70) Rgveda (X.117.4; X.71.6; 1.26.3; X.10.1; IX.86.16; X.42.11; V.11.10; 1.18.9); (Titib, 2003:551-552); Bhagavadgita (VI.9; XII.13);

3) Maitri, adab, kebaikan budhi pekerti, atau kesantunan tindakan. Maitri adalah bagian pertama dari ajaran Catur Paramita dalam agama Hindu. Ajaran keadaban juga banyak diulas dalam kitab Sarasamuccaya (2; 4-11; 73-148; 156-276).

4) Karuna, perasaan dan sikap welas asih. Karakteristik dari sikap ini adalah adanya hasrat untuk membantu dan meringankan penderitaan orang lain. Karuna adalah bagian dari ajaran Catur Paramita dalam agama Hindu. Ajaran ini juga memiliki kesamaan dengan priti (welas asih) di dalam Dasa Yama Brata.

\subsubsection{Sila ketiga: bervisi Bhineka Tunggal Ika; dan memiliki kehendak untuk bersatu.}

Keragaman adalah sifat alamiah dari kehidupan. Siapapun yang menolak keragaman maka dirinya sedang berlawanan dengan alam dan hukumnya. Agama Hindu memandang keragaman sebagai karunia kehidupan. Keragaman mengajarkan banyak kehidupan beserta maknanya. Sayangnya, keragaman tidak hanya menstimulasi kerjasama tetapi juga konflik. Pada situasi inilah dituntut adanya kesadaran kolektif tentang arti persatuan. Karena konflik, hanya menyisakan duka cita. Persatuan bukan berarti melebur perbedaan menjadi satu bentuk baru yang tunggal, yang sama. Hinduisme berpandangan bahwa persatuan mewujud dalam kesadaran, kesatuan dalam cita-cita mulia, dan kesatuan dalam visi yang positif.

Pesan-pesan persatuan dalam kebhinekaan Hinduisme dinyatakan di beberapa kitab suci, diantaranya: Rgveda (X.191.2-4; VII.79.2; X.17.10); 
Atharvaveda (III.30.1-2; III.30.5-6 1.15.2; XII.1.4.5; VII.52.1) (Titib, 2003:348-350).; Sarasamuccaya (94) (Kajeng, 1999:77-78). Berikut ini kutipan sloka dari Rgveda X.191.2-3, yang merepresentasikan pesan Hinduisme tentang persatuan dalam kebhinekaan:

Om Sam Samani va akutih samana hridayani vah

Samanam astu vo mano yathavah susahah sati

Om Hyang Widhi Wasa, tuntunlah kami agar sama dalam tujuan, sama dalam hati, bersatu dalam pikiran, sehingga kami dapat hidup bersama dengan bahagia (Titib, 2003:348-349).

\subsubsection{Sila keempat: menjunjung} tinggi kepentingan (umum) rakyat yang dijiwai permusyawaratan yang penuh hikmat.

$\mathrm{Nilai}-\mathrm{nil}$ a $\mathrm{tent}$ a $\mathrm{g}$ permusyawaratan dalam di dalam kesusastraan Hindu diungkapkan dalam kitab suci Rgveda (II.21.5; IV.21.2; VII.79.2; VIII.4.9; X.17.10; X.191.2-4; IX.86.48; IX.92.6; X.71.70;); Atharvaveda (III.30.1-2; III.30.5-6; VII.52.1; VII.12.1-2; III.29.1; VI.88.3; VII.12.2； XII.1.4.5； XX.110.2; XIX.55.5) (Titib, 2003:509-512). Berikut salah sloka dari kitab suci Atharvaveda VII.12.1, dan Atharvaveda VII.12.2, untuk merepresentasikan nilai-nilai permusyawaratan di dalam kesusastraan
Hindu :

Sabha ca ma samhitis ca-avatam prajapater duhitarau samvidante Yena samgaccha upa ma sa siksait caru vadani pitarah samgatesu

Ada dua jenis majelis permusyawaratan yaitu Sabha dan Samiti. Keduanya itu adalah putra pilihan dari para pemimpin. Mereka memiliki koordinator (yang serasi). Semoga mereka melindungi bangsa. Mereka membimbing rakyat. Semoga kami berbicara dengan hati-hati (lembut) di dalam Majelis Permusyawaratan tersebut. (Titib, 2003:510).

Nilai-nilai permusyawaratan dalam Hinduisme diaktualisasikan dalam visi kepemimpinan yang berorientasi pada kesejahteraan dan kemakmuran rakyat sebagai wujud nyata penghargaan terhadap kepentingan rakyat. Upaya-upaya untuk mewujudkan pemerintahan baik, di dalam kesusasteraan Hindu menjelaskan nilai-nilai kepemimpinan sebagai acuan. Nilai-nilai kepemimpinan di uraikan dalam kitab suci Arthasastra (VII.I.99.1-25) (Kautilya, 2003:391398); Manawa Dharmasastra (VII.1226) (Pudja dan Sudharta, 2003:353414); Nitisastra; Mahabharata; Ramayana; Bhagavadgita; Kakawin Ramayana (Sargah 21); Rgveda (I.54.11； II.16.2； X.91.2； V.37.4; VI.75.2; VII.104.25; VIII.25.16; X.37.4; X.57.1; VII.32.27; X.57.1; 
III.47.2; VII.104.3; VIII.93.11; X.27.1;

); Yajurveda (V.27; VI.36; IX.22-24; IX.40; X.17; X.28; X.21; XI.28; XII.11; XII.117; XX.3; XX.8; XX.10; XVIII.37; XIII.1; XIII.30; VII.17; XXX.5; XXXIX.7; XXXIX.9; XXXIX.39.7); Atharvaveda (V.17.3-4; IV.32.3; VIII.10.1; III.4.2; VI.87.1; X.7.31; XII.3.10); Samaveda (410; 432; 753; 971; 1006; 1608) (Titib, 2003:475-488).

Nilai-nilai kepemimpian Hindu yang menjunjung kepentingan rakyat dan berorientasi pada kesejahteraan dapat di representasikan salah satu sloka kitab suci Yajurveda XIII.1; Yajurveda XX.3 :

Agnim rayasposaya suprajastvaya suviryaya

Wahai pemimpin bagaikan api, dinobatkan untuk kemakmuran, perlindungan atas warga negara dan sifat kepahlawanan.

Balaya sriyai yasase abhisincami Terjemahan :

Wahai pemimpin, engkau dinobatkan untuk memberikan kekuatan, kemakmuran, dan kemasyuran kepada rakyat (Titib, 2003:475-476).

\subsubsection{Sila Kelima: Keadilan Sosial}

Meminjam pemikiran Yudi Latif (2011:8) bahwa keadilan sosial merupakan titik kulminasi dari aktualisasi nilai ketuhanan, nilai kemanusiaan, nilai dan cita kebangsaan, serta demokrasi permusyawaratan. Keadilan sosial harus mampu merambah dimensi-dimensi jasmani dan rohani kebutuhan manusia. Esensi dari nilai ini dapat dioperasionalisasikan dalam bentuk pemenuhan hak sipil dan politik dengan hak ekonomi, sosial dan budaya.

Keadilan adalah nilai fundamental adalam agama Hindu. Nilai ini dilandasi filosofi bahwa manusia esensi yang sama (Bhagavadgita 5.18; Yajurveda 4.60; Chandogya Upanisad 6.8.7; Hitopadesha 1.3.71; Maha Upanisad 6.72). Dalam pemahaman ini, orang lain tidak dianggap berbeda dengan dirinya sendiri, tetapi sebagai dirinya sendiri Tat Tvam Asi. Pada tataran sosial, kesadaran ini mewujud dalam tindakan-tindakan etis seperti; menyayangi (prema), welas asih (karuna), keadaban (maitri), tidak menyakiti (ahimsa), penuh persahabatan (mitra), tidak bersikap diskriminatif (samadarsinah), memikirkan kepentingan umum (lokasamgraham), bertindak atas dasar kebenaran (satya), tidak mengambil hak-hak orang lain (asteya) dan sebagainya. Kesadaran 'kesamaan' ini kemudian melahirkan sikap dan tindakan yang "tidak bisa membeda" dalam segala hal. Kitab suci Bhagavdgita 5.18, menjelaskan : Vidya vinaya sampanne brahmane gavi hastini Suni chai 'va svapake cha panditah samadarsinah Orang arif bijaksana melihat semuanya sama, baik brahmana budiman dan rendah hati maupun seekor sapi, gajah, 
dan ajing ataupun orang hina sekalipun (Pendit, 1996:154).

Keadilan sosial pada muaranya mesti dapat dirasakan pada hal-hal yang nyata dalam kehidupan, karena ia bukan sekadar retorika. Oleh sebab itu, visi kepemimpinan menjadi kata kunci dalam wacana ini. Visi dan nilai-nilai kepemimpinan dalam perspektif Hindu sudah disinggung pada penjelasan sebelumnya.

\section{Simpulan}

Berdasarkan penelusuran dan analisa, maka dapat disimpulkan bahwa nilai-nilai yang terkandung dalam Pancasila selaras atau harmoni dengan nilai-nilai yang ada di dalam agama Hindu. Simpulan itu didasarkan pada hasil analisa bahwa terjadi kesesuaian esensi atau makna dari nilai-nilai Pancasila dengan nilai-nilai yang ada di dalam kesusastraan Hindu.

Nilai-nilai Pancasila yang juga terdapat di dalam agama Hindu adalah :

1. Nilai kepercayaan terhadap eksistensi Tuhan Yang Esa; nilai religiustas sebagai basis etika berkehidupan dan bernegara; dan nilai penghargaan terhadap kebebasan berketuhanan.

2. Nilai penghargaan terhadap kemanusiaan; nilai persaudaraan universal; nilai keadilan dan nilai keadaban.
3. Nilai persatuan; nilai penghargaan terhadap perbedaan.

4. Nilai permusyawaratan atau demokrasi.

5. Nilai keadilan sosial.

\section{DAFTAR PUSTAKA}

Ismail, Nurhasan. 2006. Perkembangan Hukum Pertanahan Indonesia, Suatu Pendekatan Ekonomi Politik. Disertasi Doktor di UGM

Jalaludin. 2011. Psikologi Agama. Edisi Revisi. Jakarta:Raja Grafindo Persada

Kaelan. 2004. Pendidikan Pancasila. Yogyakarta:Paradigma

Kajeng, I Nyoman. 1999. $S$ a $r$ a $s$ a $m u$ u $c$ c a $\begin{array}{llll} & a\end{array}$. Surabaya:Paramita

Kautilya. 2003. Arthasastra. Diterjemahkan oleh Made Astana dan Anomdiputro dari buku The Kautilya Arthasastra dan Kautilya's Arthasastra. Surabaya:Paramita

Latif, Yudi. 2011. Pancasila Dasar dan Haluan Negara. Makalah dalam Lokakarya Empat Pilar Kehidupan Berbangsa dan Bernegara, (Jakarta:MPR RI 1719 Juni 2011)

Mulyadi, Dedi. 2014. Internalisasi Nilai-Nilai Ideologi Pancasila dalam Dinamika Demokrasi dan Perkembangan Ketatanegaraan Indonesia. Bandung:PT. Refika Aditama

Pendit, Nyoman S. 1996. BhagavadGita. Jakarta:Hanuman Sakti

Prabhupada, A.C. Bhaktivedanta Swami. 2006. Bhagavadgita Menurut Aslinya. Tangerang: 
Hanuman Sakti

Pudja, G dan Sudharta, Tjok. Rai. 2003. Manawa Dharmasastra atau Weda Smrti Kompendium Hukum Hindu. Jakarta:Nitra Kencana Buana

Radhakrishnan, S. 1989. Upanisad Utama Jilid I. diterjemahkan oleh Yayasan Parijata. Jakarta:Yayasan Dharma Sarati

Radhakrishnan, S. 1992. Upanisad Utama Jilid II. diterjemahkan oleh Agus S Mantik. Jakarta:Yayasan Dharma Sarati

Riyanto, Astim. 2006. Teori Konstitusi. Bandung:Yapemdo

Salam, Burhanudin. 1996. Filsafat Pancasilaisme. Jakarta:PT. Rineka Cipta

Sivananda, Swami. 2003. Intisari Ajaran Hindu. Alih bahasa Yayasan Sanatana Dharma. Surabaya:Paramita

Suriasumantri, Jujun S. 1987. Fisafat Ilmu sebuah Pengantar Poluler.Jakarta:Pustaka Sinar Harapan

Teew, A. 1984. Khasanah Sastra Indonesia. Jakarta:Balai Pustaka

Tim Penyusun. 2015. Materi Sosialisasi Empat Pilar MPR RI. Jakarta:Sekretaris Jendral MPR RI

Titib, I Made. 2003. Veda Sabda Suci Pedoman Praktis Kehidupan. Surabaya:Paramita

Titib, I Made. 2009. Teologi dan SimbolSimbol dalam Agama Hindu. Surabaya:Paramita

Titscher, Stefan Dkk. 2009. Metode Analisis Teks dan Wacana. Editor Abdul Syukur Ibrahim. Yogyakarta:Pustaka pelajar

Van Zoest, Aar. 1993. Semiotika: Tentang Tanda, Cara Kerjanya dan Apa yang Kita Lakukan Dengannya. Jakarta:Yayasan
Sumber Agung

Viresvarananda, Swami. 2004. Brahma Sutra: Pengetahuan Tentang Ketuhanan. Terjemahan Agus Mantik dari judul asli Brahma Sutras. Editor: I Wayan Waswinara. Surabaya:Paramita

Situs Internet :

http://wartakota.tribunnews.com/2017/

07/29/menristekdikti-kepadadosen-terlibat-hti-pancasila-ataukeluar-dari-kampus (diakses tanggal 31 Agustus 2017 pukul 4.16 Wib)

http://regional.kompas.com/read/2017/ 07/22/16505881/menristekdikti-beripilihan-kepada-dosen-dan-pegawaiptn-anggota-hti kampus (diakses tanggal 31 Agustus 2017 pukul 4.20 Wib). 
Dharma Duta

Jurnal Penerangan Agama Hindu Vol. 15 No. 2, 2017 